\title{
PENERAPAN PENDEKATAN SAINTIFIK UNTUK MENINGKATKAN HASIL BELAJAR SISWA PADA MATA PELAJARAN IPS MATERI PERKEMBANGAN TEKNOLOGI KELAS IV SDN KLUWIH O2 BANDAR BATANG
}

\author{
Budi Trapsilo ${ }^{1}$, Roesminingsih ${ }^{2}$, Waspodo Tjipto Subroto ${ }^{3}$ \\ Pendidikan Dasar Pascasarjana Universitas Negeri Surabaya \\ email: trapsilobudy@gmail.com
}

\begin{abstract}
Abstrak
Penelitian ini berawal dari rendahnya hasil belajar siswa kelas IV SDN Kluwih 02 Bandar Batang. Hal ini yang melatar belakangi peneliti untuk melakukan penelitian dengan menggunakan pendekatan saintifik. Pendekatan saintifik ini menekankan pentingnya langkah-langkah dalam pembelajaran, Melalui pendekatan saintifik pembelajaran menjadi berkualitas, karena pembelajarannya diarahkan untuk memandu siswa untuk memecahkan masalah melalui kegiatan perencanaan yang matang, pengumpulan data yang cermat, dan analisis data yang teliti untuk menghasilkan sebuah kesimpulan. Jenis penelitian yang dilaksanakan merupakan penelitian tindakan kelas (Classroom Action Reseach) dalam tiga siklus yang dilakukan secara kolaboratif dengan guru kelas IV. Teknik pengumpulan data yang digunakan adalah observasi untuk mengetahui aktivitas guru, aktivitas siswa, dan hasil belajar siswa. Hasil penelitian menunjukkan peningkatan bahwa (1) aktivitas guru pada siklus I, persentase keberhasilannya adalah sebesar 75\%, meningkat pada siklus II menjadi 92\%, dan meningkat pada siklus III menjadi 96\%. (2) aktivitas siswa pada siklus I, persentase keberhasilannya adalah sebesar 66,7\%, meningkat pada siklus II menjadi 89,5\%, dan meningkat pada siklus III menjadi 95,8\%. (3) hasil belajar pada siklus I, persentase keberhasilannya adalah sebesar 67\%, meningkat pada siklus II menjadi 86\%, dan meningkat pada siklus III menjadi $95 \%$. Berdasarkan hasil analisis data terdapat hubungan yang erat antara aktivitas guru, aktivitas siswa, dan hasil belajar. Semakin meningkat aktivitas guru dan aktivitas siswa semakin meningkat pula hasil belajar yang diperoleh siswa.
\end{abstract}

Kata Kunci : Pendekatan Saintifik, Hasil Belajar, IPS Sekolah Dasar.

\begin{abstract}
This research begins from the low achievement of SDN 02 Kluwih Bandar Batang years IV. It is become the background of the research that encourage the researcher to conduct a research by using scientific approach. The scientific approach emphasizes the importance of the learning stages during the teaching and learning process. Through the scientific approach the teaching and learning process reachs higher quality through the planning, careful data collection, and data analysis activities until the researcher comes into a conclusion. This type of research is Classroom Action Reseach in three cycles undertaken collaboratively with classroom teachers IV. Data collection techniques used were observation to determine the activities of the teacher, student activities, and student achievement. The results of the research showed improvement that: (1) the succeed percentage of teacher's activities during the first cycle is 75 percent, improved becomes 92 percent in the second cycle, and 96 percent in the third cycle. (2) the succeed percentage of the student's activities in the first cycle is 66,7 percent, raised become 89,5 percent in the second cycle, and 95,8 in the third cycle. (3) the succeed percentage of the students achievement in the first cycle is 67 percent, improved become 86 percent in the second cycle, and 95 percent in the third cycle. Base on the data analysis, there is a close relation between the teacher activities, the student's activities, and the student's achievement. The higher teacher activities and the student's activities, the higher achievement reaches by the students.
\end{abstract}

Keywords: Scientific Approach, Achievement, Social Studies in Elementary School.

\section{PENDAHULUAN}

Pendidikan bertujuan untuk membangun jasmani dan rohani manusia yang meliputi karakter, pengetahuan, dan keterampilannya, sehingga mampu menghasilkan manusia yang sehat dan kuat karakternya, mempunyai pengetahuan yang mumpuni, dan mempunyai keterampilan yang cakap. Membangun manusia Indonesia seutuhnya dalam pembelajaran dibutuhkan perangkat yaitu kurikulum yang merupakan bagian integral dalam proses pendidikan, karena pada hakikatnya kurikulum berada pada posisi sentral dalam setiap upaya pendidikan, artinya bahwa setiap kegiatan pendidikan yang utama adalah terjadinya proses interaksi akademik antara siswa, guru, media, dan lingkungan belajar. Posisi sentral kurikulum 
tersebut merupakan langkah strategis dalam rangka mencerdaskan kehidupan berbangsa dan bernegara serta meningkatkan kualitas manusia Indonesia seiring dengan perkembangan ilmu dan teknologi. Menurut Undang-Undang Nomor 20 Tahun 2003 tentang Sisdiknas, kurikulum adalah seperangkat rencana dan pengaturan mengenai tujuan, isi dan bahan pelajaran serta cara yang digunakan sebagai pedoman penyelenggaraan kegiatan pembelajaran untuk mencapai tujuan pendidikan nasional.

Salah satu wujud perubahan dan perkembangan dari kurikulum adalah dengan berlakunya Kurikulum Tingkat Satuan Pendidikan (KTSP) yang di dalamnya menuntut adanya perubahan paradigma pendidikan dan sistem pembelajaran. Perubahan paradigma pembelajaran yang sejalan dengan KTSP ialah orientasi pembelajaran yang semula teacher centered berubah menjadi pola interaksi pembelajaran student centered atau kegiatan pembelajaran berpusat kepada aktivitas siswa, artinya partisipasi siswa dalam kegiatan pembelajaran lebih tinggi.

Dalam KTSP terdapat mata pelajaran pokok, salah satu mata pelajaran pokok adalah Ilmu Pengetahuan Sosial (IPS). Kedudukan IPS dalam KTSP merupakan salah satu mata pelajaran yang di dalamnya mengaji seperangkat peristiwa, fakta, konsep, dan generalisasi yang berkaitan dengan isuisu sosial. Dalam paradigma pendidikan sebelumnya, mata pelajaran IPS dianggap oleh sebagian besar siswa sekolah dasar sebagai mata pelajaran yang membosankan, karena dalam proses pembelajarannya kurang mengikutsertakan peran siswa, metode yang diterapkan bersifat monoton, guru jarang menggunakan media yang menarik, dan guru masih memposisikan dirinya sebagai pusat pembelajaran. Dengan kondisi tersebut siswa merasa jenuh, tidak kreatif, dan malas mengikuti pembelajaran sehingga hasil pembelajaran tidak sesuai dengan KKM yang diharapkan.

Salah satu problema yang dihadapi oleh sebagian guru adalah kurangnya kreativitas dalam pembelajaran, sehingga tujuan pembelajaran masih kabur dan melenceng dari tujuan yang diharapkan. Pembelajaran IPS seharusnya berpusat pada siswa (student centered) dan bukan berpusat pada guru (teacher centered). Paradigma student centered menyatakan bahwa pembelajaran harus melalui aktivitas yang kompleks oleh siswa selama proses pembelajaran, bersifat kontekstual, dan mendukung adanya kolaborasi antar siswa untuk mencapai pembelajaran yang bermakna. Pembelajaran juga harus berorientasi pada pemecahan masalah melalui produk nyata. Fakta di lapangan berbicara sebaliknya, pembelajaran masih di dominasi guru sebagai sumber utama ilmu pengetahuan. Sumber belajar utama berasal dari buku paket, aktivitas belajar siswa seputar mencatat dan mendengar penjelasan guru, pembelajaran kooperatif yang belum efektif, sehingga hasil belajar yang mendapatkan belum optimal dan perlu ditingkatkan.

Menurut Sanjaya (2006: 19), peran guru adalah sebagai sumber belajar, fasilitator, pengelola, demonstrator, pembimbing dan evaluator. Sebagai motivator, fasilitator dan pembimbing, guru harus meningkatkan aktivitas siswa dalam proses pembelajaran. Pembelajaran yang dilakukan antara guru dan siswa harus mengacu pada peningkatan aktivitas dan partisipasi siswa. Guru tidak hanya melakukan kegiatan menyampaikan pengetahuan, keterampilan dan sikap kepada siswa, tetapi guru juga harus mampu membawa siswa untuk aktif dalam berbagai bentuk belajar, berupa belajar penemuan, belajar mandiri, belajar kelompok, belajar memecahkan masalah dan sebagainya.

Berdasarkan hal di atas, maka peneliti berusaha mencarikan solusi pembelajaran lain yang lebih efektif untuk meningkatkan hasil belajar dan mendukung pengembangan potensi siswa secara optimal baik dari segi kognitif, afektif maupun psikomotorik. Menurut Joyce, Weil \& Calhoun (2011: 6-7) model-model pengajaran bisa dianggap sebagai model-model pembelajaran, model pengajaran atau disebut juga model pembelajaran merupakan hasil dari perjuangan guru yang berhasil membuat reportoar tentang berbagai praktek pengajaran agar mereka dapat berinteraksi dengan para siswa dan mempertajam lingkungan atau suasana saat mengajar siswa-siswanya. Beberapa praktik ini menjadi sasaran kajian formal, diteliti, dan dipoles sehingga menjadi model yang dapat digunakan dalam mengembangkan skill-skill profesional untuk tugas-tugas pengajaran. Salah satu ciri khusus pendekatan pembelajaran yang tidak dimiliki oleh strategi atau prosedur tertentu yaitu tingkah laku mengajar (sintaks) yang menggambarkan pola kegiatan guru dalam mengajari siswa untuk belajar memperoleh informasi, gagasan, skill, nilai, cara berpikir, dan tujuan mengekspresikan diri mereka sendiri, sehingga tujuan pembelajaran dapat tercapai. Salah satu solusi untuk menciptakan pembelajaran yang kritis, dapat memecahkan masalah, dan 
meningkatkan keterampilan dalam kehidupan sosial bagi siswa diperlukan pendekatan saintifik. Alasan diterapkan pendekatan saintifik, karena melalui pendekatan saintifik siswa mampu mengembangkan pola pikir yang kritis dan meningkatkan keterampilan sosial siswa sesuai dengan keterampilan dalam pendekatan saintifik yaitu melakukan pengamatan, menanya, mencoba, menalar, dan mengkomunikasikannya.

Pendekatan saintifik adalah proses pembelajaran yang memandu siswa untuk memecahkan masalah melalui kegiatan perencanaan yang matang, pengumpulan data yang cermat, dan analisis data yang teliti untuk menghasilkan sebuah kesimpulan (Abidin, 2014: 125). Pendekatan saintifik dimaksudkan untuk memberikan pemahaman kepada siswa dalam mengenal, memahami berbagai materi menggunakan pendekatan ilmiah, informasi bisa berasal dari mana saja dan kapan saja, selain itu informasi tidak hanya tergantung dari guru. Oleh karena itu kondisi pembelajaran yang diharapkan tercipta diarahkan untuk mendorong siswa dalam mencari tahu dari berbagai sumber melalui obsevasi, dan bukan hanya diberi tahu (Hosnan, 2014: 34).

Berdasarkan uraian yang dikemukakan, maka rumusan masalah dalam penelitian ini adalah 1) Bagaimanakah aktivitas guru dalam pembelajaran dengan pendekatan saintifik pada materi Perkembangan Teknologi siswa kelas IV SDN Kluwih 02 Kecamatan Bandar Batang? 2) Bagaimanakah aktivitas siswa dalam pembelajaran dengan pendekatan saintifik pada materi Perkembangan Teknologi siswa kelas IV SDN Kluwih 02 Kecamatan Bandar Batang? 3) Bagaimanakah pendekatan saintifik dapat meningkatkan hasil belajar siswa pada mata pelajaran IPS materi perkembangan teknologi kelas IV SDN Kluwih 02 Bandar Batang?

\section{METODE}

Jenis penelitian yang dilaksanakan merupakan penelitian tindakan kelas (Classroom Action Reseach), yang mempunyai tujuan untuk mendapatkan data kegiatan pembelajaran yang dijumpai di kelas untuk memperbaiki proses pembelajaran pada suatu kelas. Ada tiga pengertian yang dapat diterangkan : (1) Penelitian, menunjuk suatu kegiatan mencermati suatu objek dengan menggunakan cara dan metodelogi tertentu untuk memperoleh data/informasi yang bermanfaat dalam meningkatkan mutu suatu hal yang menarik minat dan penting bagi peneliti; (2) Tindakan, menunjuk pada suatu gerak kegiatan yang sengaja dilakukan dengan tujuan tertentu, dalam penelitian berbentuk rangkaian siklus kegiatan; (3) Kelas, dalam hal ini tidak terkait pada pengertian ruang kelas, tetapi dalam pengertian yang lebih spesifik yaitu, sekelompok siswa yang dalam waktu yang sama, menerima pelajaran yang sama dari guru yang sama pula (Arikunto dkk, $2012: 2-3$ ).

Sedangkan menurut Mulyasa (2013: 11) penelitian tindakan kelas merupakan suatu upaya untuk mencermati kegiatan belajar sekelompok peserta didik dengan memberikan sebuah tindakan (treatment) yang sengaja dimunculkan.

Pendapat lain tentang PTK dikemukakan oleh Kemmis dan Taggart (dalam Ulfatin, 2014:108) PTK adalah suatu bentuk penelitian tentang refleksi diri yang secara kolektif dilakukan peneliti dalam situasi sosial untuk meningkatkan penalaran dalam praktik pendidikan. Model yang digunakan dalam penelitian ini adalah yang dikembangkan oleh Kemmis dan Mc Taggart. Lebih jelas tentang PTK, Kemmis dan Taggart mendefinisikannya dalam bagan berikut.

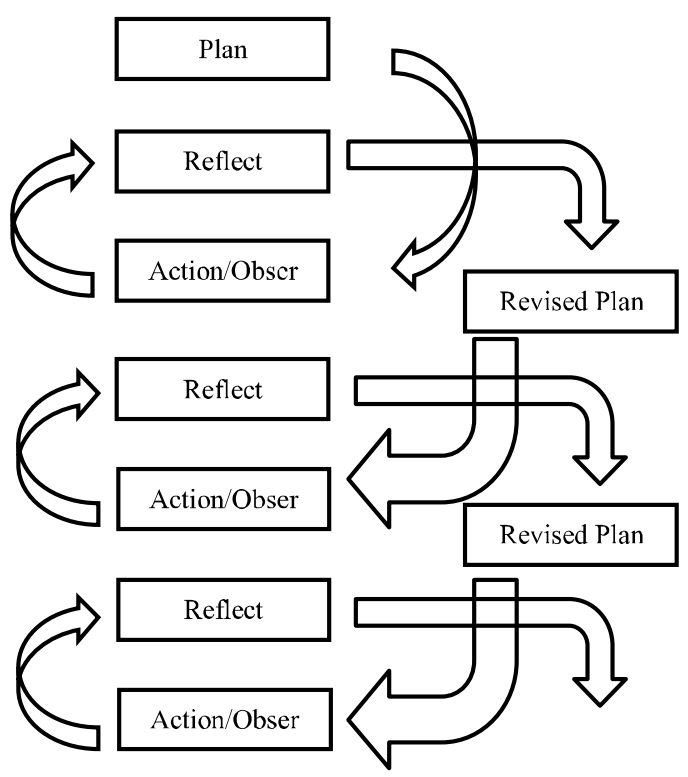

Gambar 1. Proses Penelitian Tindakan Kelas (Adaptasi dari Kusumah, 2012:21)

\section{HASIL DAN PEMBAHASAN}

Hasil penelitian ini disusun berdasarkan data yang diperoleh dari kegiatan pembelajaran yang telah dilaksanakan oleh guru kelas IV di SDN Kluwih 02 Bandar Batang Jawa Tengah pada 
tanggal 23 April -8 Mei 2015. Penelitian ini bertujuan untuk meningkatkan hasil belajar pada mata pelajaran IPS, materi Perkembangan Teknologi siswa kelas IV dengan menggunakan pendekatan saintifik.

\section{A. Aktivitas guru dalam pembelajaran}

Pada siklus I aktivitas guru diketahui bahwa dalam kegiatan pendahuluan apersepsi dan motivasi yaitu menyiapkan fisik dan psikis peserta didik dengan menyapa dan memberi salam sudah dilaksanakan dengan sangat baik. Pada tahap mengaitkan materi pembelajaran sekarang dengan pengalaman peserta didik atau pembelajaran sebelumnya dan mengajukan pertanyaan menantang, guru mendapat kriteria baik. Pada penerapan pendekatan saintifik, tahap memfasilitasi kegiatan pengamatan siswa, dan memberi, menggali, dan merangsang siswa untuk bertanya, guru mendapat nilai baik. Selanjutnya tahap memfasilitasi siswa dengan penalarannya sendiri, memfasilitasi siswa untuk melakukan percobaan, memfalisitasi hasil kerja siswa untuk dikomunikasikan, dan memfasilitasi siswa untuk menyimpulkan materi melalui kegiatan tanya jawab, guru mendapat nilai cukup. Pada penutupan pembelajaran tahap melakukan refleksi atau membuat rangkuman dengan melibatkan peserta didik, memberikan tes lisan atau tulisan, dan melaksanakan tindak lanjut dengan memberikan arahan kegiatan berikutnya dan tugas pengayaan, guru mendapat nilai baik. Pada penerapan strategi pembelajaran, tahap melaksanakan pembelajaran secara runtut, guru mendapat nilai sangat baik, menguasai kelas mendapat nilai baik, melaksanakan pembelajaran yang bersifat kontekstual, guru mendapat nilai sangat baik. Sedangkan tahap Melaksanakan pembelajaran sesuai dengan alokasi waktu yang direncanakan, guru mendapat nilai cukup. Pada penggunaan bahasa yang benar dan tepat dalam pembelajaran tahap menggunakan bahasa lisan secara jelas dan lancar, menggunakan bahasa tulis yang baik dan benar, guru mendapat nilai sangat baik. Jumlah skor yang peneliti peroleh adalah dalam pelaksanaan pembelajaran pada siklus I skor yang diperoleh adalah 54 dan skor maksimalnya 72 dan persentase aktivitas guru $75 \%$.

Aktivitas guru dalam pembelajaran siklus II telah mengalami peningkatan sebesar $17 \%$ dari siklus I dengan proentase $92 \%$. Hal ini terlihat peningkatan pada penerapan pendekatan saintifik, tahap memfasilitasi kegiatan pengamatan siswa, dan memberi, menggali, dan merangsang siswa untuk bertanya, guru mendapat nilai baik. Selanjutnya tahap memfasilitasi siswa dengan penalarannya sendiri, memfasilitasi siswa untuk melakukan percobaan, memfalisitasi hasil kerja siswa untuk dikomunikasikan, dan memfasilitasi siswa untuk menyimpulkan materi melalui kegiatan tanya jawab, meningkat dari cukup ke baik. Pada penutupan pembelajaran tahap melakukan refleksi atau membuat rangkuman dengan melibatkan peserta didik, memberikan tes lisan atau tulisan, dan melaksanakan tindak lanjut dengan memberikan arahan kegiatan berikutnya dan tugas pengayaan, guru mendapat nilai baik. Pada penerapan strategi pembelajaran, tahap melaksanakan pembelajaran secara runtut, guru mendapat nilai sangat baik, menguasai kelas mendapat nilai baik, melaksanakan pembelajaran yang bersifat kontekstual, guru mendapat nilai sangat baik. Alokasi waktu yang direncanakan, juga telah diperbaiki walaupun belum sepenuhnya sesuai rencana.

Aktivitas guru selama proses pembelajaran pada siklus III sudah katakan berhasil karena telah mencapai persentase ketuntasan $96 \%$. Hanya dua aspek saja yang belum bisa ditingkatkan oleh guru, yaitu mengajukan pertanyaan menantang dan memfasilitasi siswa dengan penalarannya sendiri, hal ini masih bisa dimaklumi karena pendekatan saintifik ini baru sekali diterapkan oleh guru.

Secara keseluruhan aktivitas guru dari siklus I, II, dan III telah terjadi peningkatan, dari kegiatan apersepsi dan motivasi, penerapan strategi pembelajaran, penerapan pendekatan saintifik, dan kegiatan penutup guru telah berhasil dan mendapat nilai dengan kategori sangat baik. Namun dalam apersepsi dan motivasi aspek mengajukan pertanyaan menantang guru belum bisa memberikan pertanyaan yang menantang yang merangsang siswa untuk masuk kedalam materi pelajaran. Dalam kegiatan inti, aspek memfasilitasi siswa dengan penalarannya sendiri, guru belum sepenuhnya berhasil memberikan cara supaya anak dapat melakukan kegiatan penalaran dengan baik. 


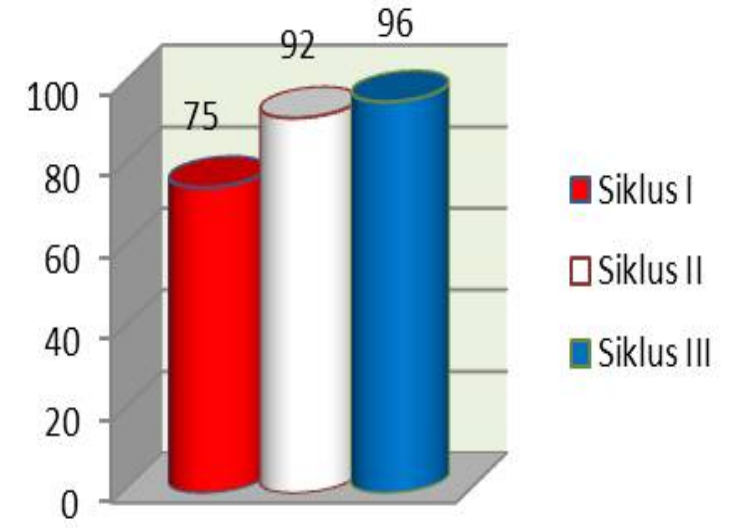

Gambar 2. Aktivitas guru siklus I, II, dan III

B. Aktivitas siswa dalam pembelajaran

Aktivitas siswa adalah seluruh kegiatan yang dilakukan siswa selama proses pembelajaran. Aktivitas siswa yang diamati adalah mendengarkan penjelasan guru, mengamati, menanya, menalar, mencoba, mempresentasikan, menjawab serta menanggapi, dan menyimpulkan hasil diskusi.

Pembelajaran dengan pendekatan saintifik guru secara terus menerus membimbing siswa siswa dalam kegiatan pengamatan, mengajukan pertanyaan, menalar, melakukan percobaan, mengomunikasikan, dan menyimpulkan. Dengan demikian pembelajaran dengan pendekatan saintifik dapat meningkatkan aktivitas siswa dalam pembelajaran.

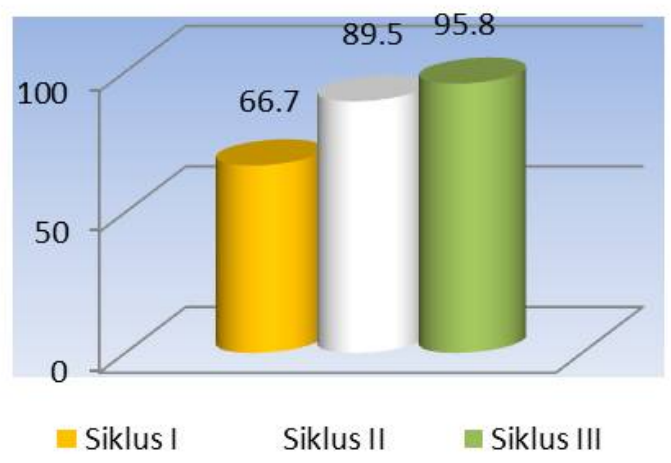

Gambar 3. Aktivitas siswa siklus I, II, dan III

\section{Hasil Belajar Siswa}

Hasil belajar merupakan tingkat pencapaian hasil belajar yang diukur dengan skor, diperoleh berdasarkan tes hasil belajar setelah mengikuti pembelajaran yang disusun dan dikembangkan oleh peneliti. Tes hasil belajar merupakan bagian dari evaluasi yakni kegiatan mengumpulkan data seluasluasnya yang bersangkutan dengan kemampuan siswa guna mengetahui sebab akibat dan hasil belajar siswa yang dapat mendorong dan mengembangkan kemampuan belajar.

Hasil belajar yang dicapai siswa pada setiap siklus menunjukan perbedaan yang signifikan. Rata-rata nilai tes hasil belajar siswa pada siklus I masih dibawah KKM yaitu $67 \%$, meningkat menjadi $86 \%$ pada siklus II, dan $95 \%$ pada siklus III, dari 21 orang siswa yang mengikuti pembelajaran ini hanya 1 orang yang nilainya berada di bawah KKM pada siklus III. Solusi untuk anak tersebut adalah dengan memberikan remedial. Perbedaan nilai hasil dari siklus I sampai siklus III dapat dijadikan salah satu bukti bahwa pembelajaran dengan pendekatan saintifik dapat meningkatkan hasil belajar siswa.

Berikut disajikan diagram peningkatan hasil belajar siswa dalam pelaksanaan pembelajaran.

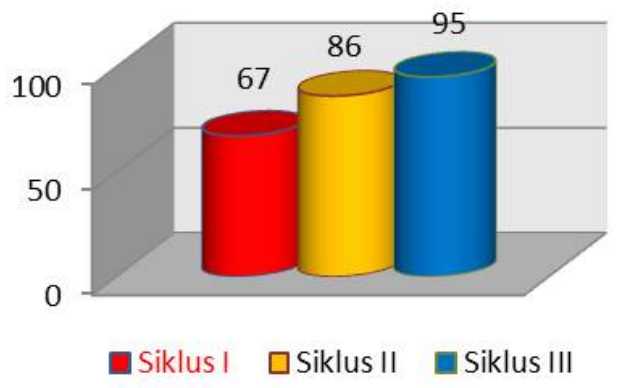

Gambar 4. Perbandingan Hasil Belajar Siswa Siklus I, II, dan III

Berdasarkan diskusi hasil penelitian di atas, terdapat hubungan yang erat antara aktivitas guru, aktivitas siswa, dan hasil belajar. Semakin meningkat aktivitas guru dan aktivitas siswa semakin meningkat pula hasil belajar yang diperoleh siswa.

\section{PENUTUP}

Aktivitas guru dalam menerapkan pendekatan saintifik dalam pembelajaran pada setiap siklusnya menunjukkan peningkatan. Peningkatan tersebut berdampak positif pada tercapainya langkah-langkah pembelajaran, yaitu mendorong siswa untuk melakukan kegiatan pengamatan, melakukan tanya jawab, melakukan penalaran, melakukan percobaan, mengomunikasikan hasil, dan menyimpulkan.

Aktivitas siswa dalam pembelajaran dengan pendekatan saintifik meningkat. Peningkatan tersebut dapat dilihat dari rata-rata aktivitas siswa 
dan persentase keberhasilan yang telah dicapai dari siklus I hingga siklus III.

Hasil belajar siswa kelas IV SDN Kluwih 02, Bandar, Batang pada pembelajaran IPS dengan menerapkan pendekatan saintifik meningkat secara signifikan. Peningkatan ini bisa dilihat dari siklus I sampai siklus III, yang ditunjukkan dengan ketuntasan klasikal yang meningkat pada setiap siklus.

Guru sebaiknya menggunakan pendekatan saintifik dalam pembelajaran karena dapat berdampak positif pada tercapainya langkahlangkah pembelajaran, yaitu mendorong siswa untuk melakukan kegiatan pengamatan, melakukan tanya jawab, melakukan penalaran, melakukan percobaan, mengomunikasikan hasil, dan menyimpulkan.

Guru sebaiknya menggunakan pendekatan saintifik dalam pembelajaran karena aktivitas siswa dalam pembelajaran dengan pendekatan saintifik meningkat.

Penerapan pendekatan saintifik pada materi perkembangan teknologi menunjukkan hasil yang baik, maka sebaiknya guru menerapkan pendekatan saintifik pada materi lain yang sesuai dengan pendekatan saintifik.

\section{DAFTAR PUSTAKA}

Abidin, Yunus. (2014). Desain Sistem Pembelajaran Dalam Konteks Kurikulum 2013. Bandung: PT. Refika Aditama.

Arikunto, Suharsimi., Suhardjono dan Supardi. (2012). Peneltian Tindakan Kelas. Jakarta: Bumi Aksara.

Hosnan, M. (2014). Pendekatan Saintifik dan Kontekstual dalam Pembelajaran Abad 21. Bogor: Ghalia Indonesia.

Joyce, Bruce., Weil, Marsha dan Calhoun, Emily. (2011). Model of Teaching. Yogyakarta: Pustaka Pelajar.

Mulyasa, E. (2013). Praktik Penelitian Tindakan Kelas. Bandung: Remaja Rosdakarya.
Sanjaya, Wina. (2006). Strategi Pembelajaran Berorientasi Proses Standar Proses Pendidikan. Jakarta: Kencana Prima.

Ulfatin, Nurul. (2014). Metode Penelitian Kualitatif di Bidang Pendidikan: Teori dan Aplikasinya. Cet. Kedua. Malang: Bayumedia Publishing.

Undang-undang Nomor 20 tahun 2003 tentang Sistem Pendidikan Nasional. 